\section{THE DARWINIAN “WORKING HYPOTHESIS OF EVOLUTION" EXAMINED PHYSIOLOGICALLY.}

\author{
BY T. WHARTON JONES, F.R.C.S., F.R.S.
}

ACCORDING to the Epicurian doctrine recited by Lucretius in his poem "De Rerum Naturâ," "it was not by design that atoms framed the world; but after many fruitless collisions they chanced to fall into such motions as produced the world and all that is in it. At first monsters of all kinds were formed, which could not grow up nor continue their kind. They all therefore perished off." "The members and organs of the body," further said Lucretius, "were not formed by design, but having been formed, came to be applied to the uses for which they were found adapted." Whilst Epicurus thus taught that organised structure determined function, M. Lamarck, in his "Philosophie Zoolcgique," published in France about eighty years ago, formulated a scheme of evolution, according to which " it was not the form of the body or of its parts which gave rise to the habits and mode of life of animals, but, on the contrary, it was the habits and mode of life, together with other influences, which have in the course of time-ages and ages-determined the form of the body and parts of animals." Nay, new organs having become necessary in consequence of new wants, efforts were made by animals to acquire the desiderated organs, and so, according to Lamarck, they came into existence! In a similar strain, Dr. Erasmus Darwin, in this country, argued that the acquisition of new organs in the course of the erolution of animals was the result of their own nisus or endeavour to obtain what they longed for! The late $\mathrm{Mr}$. Charles Darwin, grandson of Dr. Erasmus Darwin, objected to the scheme traced out by Lamarck, as affording no explanation of the process by which organised bodies have been evolved from the lowest to the highest. The efficient cause in operation, according to Mr. Darwin's own view, has been what he designated "natural selection"-a process described by him as follows: "Amid the struggle for existence which has been always going on among living beings, variations of bodily conformation and structure, if in any degree profitable to an individual of any species, will tend to the preservation of that individual, and will generally be inherited by its offspring. Thus is "survival of the fittest" the condition for "natural selection.'

This formula of evolution by "natural selection, by survival of the fittest in the struggle for existence," seems, in reality, no more than what Epicurus taught in Athens, and after him Lucretius sang in Rome, and is no explanation, but merely a form of words without any basis in fact. I have, however, seen it somewhere actually stated that $\mathrm{Mr}$. Darwin discovered natural selection-an amusing example of confusion of ideas respecting the difference between discovery and invention. The fundamentally similar construction of the human arm and hand, for example, the forelegs and feet of quadrupeds, wings of bats, flappers of seals, paddles of whales, and wings of birds, is, argued Mr. Darwin, inexplicable on any other supposition than common descent. All this, again, it must be affirmed, is a mere conceit, a conclusion without premisses. Such similarity of plan in the construction of their organs does not logically prove that the different races of animals have been evolved, the highest from the lowest, in the manner alleged. The process of change in the course of ontogenesis or the development of the embryo from the ovum to the state of the grown animal comprises a differentiation of structure; but, let it be particularly remembered, this differentiation is a real and observable development, and must not be confounded with the imaginary differentiation by transmutation, arbitrarily assumed by evolutionists to be the process of change in what they call phylogenesis or evolution of the line. Any rariation in the development of an embryo, whether by excess or defect of the normal structure which may take place, is merely a monstrosity. In main features, the early human embryo does not, at first glance, seem to differ much from the correspondingly early embryo of a dog, for example; but notwithstanding this, they differ potentially from each other. By virtue of internal qualities and hidden power, the two somewhat similar aggregations of cells are at last unerringly developed-the one into a man and the other into a dog.

That races of living beings have had their form and structure, and consequently their functional endowments, transmuted by natural selection or any other imaginary process of evolution in a long course of ages, and that they have thereby become different from the organisms whence they sprang, are propositions not supported by any legitimate induction from facts. In the metamorphoses of the frog we can observe how the limbs and lungs make their appearance, and how the tail and gills of the tadpole disappear, so that the animal from being virtually a fish comes to be an airbreathing batrachian. These changes of structure and function constitute natural stages in the ontogenesis or process of development of the individual. The hind legs are first formed and assist the tadpole in swimming; but when the fore legs become, in due course, free, and the animal thereby fitted for progression on land, the tail, which was previously the organ of progression in the water, shrinks and disappears, while t!e gills for respiration in water are superseded by lungs for breathing air. In consequence of the diversion of the circulation of the blood from the tail, it becomes atrophied and reduced to a crust, which eventually falls off; the tail is not detached bodily, as commonly alleged. In a similar manner, the gills disappear by becoming atrophic in consequence of the diversion of the circulation of the blood from them to the swimming bladder now becoming lungs. All this process of metamorphosis, let it be repeated, constitutes an invariable stage in the ontogenesis or natural course of development to the frog state, and is no exhibition of a differentiation by transmution, such as is assumed to take place in what is called phylogenesis or evolution of the line. The transitional resemblances of form, the homologies and analogies of structure observable in the different races of organised beings, cannot, then, be admitted as indicative of any such thing as a proof of progressive evolution whereby plants or aniia als have by chance, or spontaneously, or by natural selection, whichever you choose to call the conceit, been transmuted from a lower to a higher grade of organisation with corresponding elevation of endowments. Though there is a resemblance among organic forms so far as to indicate a unity in the plan of the whole, a line of demarcation circumscribes, and has circumscribed so far as our cognisance truly extends, each kind or form.

An exposition of the affinities, the homologies and adaptations of structure throughout the organic kingdoms, is a great aim of philosophical anatomy; and the subject has been long ago pretty successfully worked out, even to the discovery of new facts and to the tracing of the transition between invertebrates and vertebrates (a transition, however, not through an ascidian mollusk, as Mr. Darwin fantastically thought he had discovered); but how well made out soever the affinities, homologies, and adaptations of structure may be, and how valuable a key soever to the discovery of new facts the knowledge thereof has proved, their demonstration does not and cannot, from the very nature of the question, help to confirm scientifically the doctrine of evolution; it is a mere sophism to argue otherwise. The question is one beyond the pale of science, and any addition of facts of the kind appealed to will still fail to fill up the proof.

A word about nucleated cells. The nucleated cell is a microscopical corpuscle of albuminous nature in respect to substance, and in respect to structure comprises two distinct parts - viz., protoplasm and nucleus. These two parts are usually enclosed within a membraneous wall -a third element of structure; but this cell-wall, though it has given name to the whole corpuscle, is found not to be a constant or essential part of its structure. A lower phase of living, or at least viable, existence than the nucleated cell is found in the cytode-a shapeless mass of protoplasm without a nucleus, and which is assumed by evolutionists to have originated by spontaneous generation. Though originally homogeneous in composition, structure, and endowments, cytodes, nucleated cells, and tissues developed from them, have come at last, according to evolutionists, to form, by a process of differentiation, the various kinds of corpora viva. In contradiction of this, however, it is important to remember a fundamental principle in the biology of cells, a fundamental principle overlooked or ignored by evolutionists-viz., that cells are of various kinds, each kind possessing its own peculiar vital endowments and its own mode of further development. One kind of cells does not 
give origin to another kind of different endowments. There is no such thing known as differentiation in the sense in which evolutionists have come to employ the term-viz., transmutation of endowments as well as of substance and structure-comparable to the transmutation of baser metals into gold, as pretended by the alchemists. Here I may repeat the remark made in my article on the Ova of Man and the Mammifera, that "differentiation" is a word which was imported by Professor von Baer into the vocabulary of development, but which has since $\operatorname{come}$ to be illogically usurped by evolutionists, as if, instead of merely indicating steps observable in the development which goes on before our eyes, it represented a real fact in proof of the evolution of organised and living beings from the lowest to the highest in all their various species, genera, and classes throughout millions of years-a phylogenesis which they fancy and gratuitously assume to have taken place.

The truth is, all that we know of cells is that they run through the different phases of growth and development proper to them, each kind according to its own fixed destiny. Granting any number of generations through which cells may be supposed to have descended, the evolution argument is not thereby strengthened or confirmed. When, by virtue of their own original intrinsic qualities, differently composed and endowed cells are, under the appropriate conditions, developed into tissues, each kind in its own proper way, the process is truly one of "differentiation" in the sense in which it was first employed in embryology by von Baer, but there is certainly no such process in nature, if by the expression is meant the development by transmutation of different kinds of tissues from one and the same kind of cells by their own desires and efforts with the resulting formation of new organs with correspondingly new endowments. The reality of such an imaginary process is, in fact, the very point to be contested, as the false foundation on which the superstructure of evolution has been in a great measure built.

Though resembling each other in their general characters, organic cells, let it be repeated, are of various kinds, each kind possessing its own peculiar endowments, physical and vital, and its own mode of further development into tissues and organs. One kind of cells cannot give origin to another kind with different endowments, nor be developed by the chance of circumstances into this or that kind of structure Cells react vitally under varying conditions, but each kind only in its own way. If the conditions be unusual, the cell still reacts after its own manner, according to its inherent potentialities, so far as the unusual conditions permit. Cells may, indeed, become morbid, languish, and die under the influence of unfavourable conditions, but they never react in such a way as to be converted by transmutation of substance or evolutionary differentiation into some structure and organ of a fundamentally different nature from that which is normally the product of their development.

The elements in respect to shape composing the various tissues of the organs of a corpus vivum are formed out of the substance of cells, their nuclei, and intercellular substance; and though thus similar in the mechanism of their development, organs differ from each other, not only in shape and structure, but also in endowments, physical and vital-a necessary result from their component tissues being developed each from its own kind of cells. In short, the various cells, though they may resemble each other in external aspect and general points of structure, and the endowments thereon depending, are intrinsically different in their potential vital qualities. No transmutation, therefore, can, under any circumstances, take place of one lzind of cell into the structure which is the proper product of the development of another kind of cell; nor can one kind of glandular cell elaborate the secretion which is produced from another kind. That the peculiarly endowed brain cells of man could ever have been evolved in the course of any number of generations throughout millions of years from the differently endowed brain cells of lower animals, is the merest fancy, as is, of course, also that any increased mental activity of an ape could have led to the evolution of the human mind.

Admitting that the nature of the pbysiological factors to which evolution is due is still open to discussion, and thus quietly giving up the form of words excogitated by $\mathrm{Mr}$. Darwin to designate the efficient cause of evolution-viz., natural selection by survival of the fittest-evolutionists now fall back upon the palæontological facts disclosed by geology as decisive historical proof that evolution has actually taken place. For example, the one-toed horse of the present day was preceded on the earth by a three-toed horse, and it is assumed that the former has been evolved from the latter by the suppression of the phalanges of its rudimentary toes and other slight modifications. But supposing, for argument's sake, this descent of a one-toed from a three-toed horse, it would go a very little way in support of the doctrine of evolution by transmutation of structure and endowments, such as the evolution of the human brain from that of apes Children are sometimes born with six toes, and reproductions of the malformation in the family are not uncommon but herein we have no example of a new and improved edition of the breed. In regard to the three-toed fossil hipparion, we may indeed recognise in its bones and teeth characters indicating a near relationship to the horse tribe of the present day. We may also recognise, on the other hand, in the embryo of the said tribe indications of a threetoed development; but to say, for that reason, that a horse, a zebra, or an ass has been evolved from the prehistoric hipparion by natural selection, by survival of the fittest, is a logical inconsequence. All that palæontology teaches us is that various organic forms have in succession lived on the earth in the course of long periods of time, and that such forms, in like manner as the various forms of the present day actually do, exhibit in their fossil remains a close resemblance to each other in their transitional homologies. Herein it is obvious that we have no logically scientific proof that the organic forms, of which the fossil remains are first found in the strata of a later geological epoch, had been any one of them (e.g., the horse-tribe of the present day) evolved by transmutation of structure and endowments in fortuitous succession from a different form-e.g., the hipparion, of which the fossil remains are found in strata of an earlier geological period. This fallacious attempt to prove the validity of evolution by an appeal to palæontology is not to be confounded with the perfectly logical endeavour of Cuvier to construct from the study of fossil bones and teeth as data an anatomical and physiological history of the animals, of which the said bones and teeth are the actual remains. If, in the alleged evidence from palæontology, we had really a logical proof that evolution of organic forms in the manner contended for has actually taken place, it would then not be so difficult to understand the nature of the physiological factors in operation, even though the process may have been one requiring millions of years for its accomplishment. We should, however, have to admit that one kind of cells can give origin to other kinds which may be developed by the chance of circumstances into this or that kind of structure with this or that kind of endowments. The process in such a case would be similar to that in the development of the frog, as above described, but taking place fortuitously with the superaddition of differentiation by transmutation of structure and endowments.

In regard to the evolution of mind and language Mr. Darwin gave utterance to the speculation that the continued use of language has led to the evolution of the intellect, notwithstanding that it is self-evident language presupposes already existing intelligence as well as the proper organs of voice and speech. Then, again, it may be asked did the nisus to speak lead to the evolution of the organs of voice and speech, or did speech follow the fortuitous evolution of the organs? Leaving such niaiseries aside, let Professor Max Müller speak:- "The words in all languages," says he, "are built up from comparatively few roots, so that the whole question of the origin of language narrows itself into the problem of the origin of roots. All living things are built up of small cells, and evolutionists are anxious to picture cells uniform from the beginning. Roots of words are the cells of philological science, but the philologist sees no evidence that their number can be much reduced, or that they can possibly be traced to a single source. Roots are neither interjections nor imitations of the sounds of nature, and it is utterly impossible that they could have been formed till the animal began to generalise from observed facts and began co have the power of counting. The intellect and the language of man began at the same time, so there must have been a definite and distinct line at the outset separating man from the lower animals."

Postscript.-In the Nineteenth Century for November there is an eloquent article by Mr. Gladstone on the "Dawn of Creation and Worship," which has called forth a reply in the same magazine for December by Professor Huxley, 
under the title of the "Interpreters of Genesis and the Interpreters of Nature," to which, in the January number, Mr. Gladstone has published a rejoinder under the title of "Pröem to Genesis-a Plea for a Fair Trial."

Mr. Gladstone's aim is to vindicate the inspired authority of Genesis against Dr. Réville's "Prolegomena to the History of Religions." Admitting that the Mosaic account of the sequence of creative acts is not quite borne out by the observed facts of geology and palæontology, but recognising the "days" as geological periods, he contends that the two accounts are in sufficiently substantial agreement. Though not formally impugning the Darwinian doctrine of evolution, he objects to it as not affording any solution of the great arcanum of creation, seeing that a merely corporeal evolution would not account for the origin of mind and spirit. Besides this, he protests against the doctrine on account of the atheism involved in it.

Mr. Huxley's reply, in correction of Genesis, and in opposition to Mr. Gladstone's views, comprises a scientific exposition of the observed facts of geology and palæontology relating to the succession in the appearance on the earth of the various kinds of plants and animals. This exposition, however, does not prove the validity of the Darwinian hypothesis of evolution, which, notwithstanding all that has been said for it, still remains unverified and unverifiable. See page 68 of my lectures, entitled "Evolution of the Human Race from Apes and of Apes from Lower Animals-a Doctrine unsanctioned by Science" (1876). From this volume I may here, in conclusion, quote the following passage: "It is commonly assumed by evolutionists, and tacitly granted them, that there are only two fundamental alternatives between which a definite decision has to be made-viz., revelation or evolution. But this 1 emphatically deny. Unbelief in revelation and a personal Creator is no doubt the alternative of the admission of evolution, but admission of evolution is not the necessary alternative of unbelief. Excluding all belief in revelation and a personal Creator, for argument's sake, I hold that the doctrine of evolution, unsanctioned, as I believe I show it to be, by science, cannot be accepted as the alternative on any consideration, and must therefore be unconditionally and absolutely rejected."

\section{A NOTE ON ABDOMINAL SECTIONS.}

BY W. F. WADE, F.R.C.P.

SENIOR PHYSICIAY TO TIIE GENERAC HOSPITAL, BIRMINGHAM.

THe mention of my name in Mr. Lawson Tait's paper on Cholocystomy reminds me of a purpose which has been for some time in my mind. I wish to address a few words to those who, like myself, are exclusively, and to those who, as general practitioners, are chiefly, engaged in the treatment of medical as distinguished from surgical cases. Before us, acting in this capacity, cases come which no doubt are in their inception properly catalogued as medical, and which a few years ago would have remained so to their termination. Medicine might fail, but surgery had nothing to offer. That is not so now. The Birmingham school of gynæcological surgeons has increased the resources of civilisation, and their fellows elsewhere are, somewhat slowly and reluctantly perhaps, following in their footsteps. But the sick public will not have the full benefit of these new resources till we who practise medicine give our fiat and sanction to them. Ought we to do so? I am not a surgeon, and therefore am not swayed by a desire to operate whenever an operation is possible, as some suppose habile operators to be swayed. On the contrary, I feel always a certain amount of chagrin when compelled to say, "Medicine is powerless, but surgery is not." Yet I' feel obliged to admit that in some cases, which, as already pointed out, have up to now been regarded as exclusively medical, our efforts ought to be supplemented or supplanted by those of the surgical operator. Another question now naturally arises: In what class of cases, and to what extent in that class? This is a question which I regard as still sub judice. Instead, then, of attempting to give a direct answer, for which the time has not yet come, 1 will very briefly narrate four cases which have happened to me in the ordinary course of private practice within the last six months, in which I suggested the advisability of abdominal section, and in which, in accordance with that advice, it was performed.

1. The patient mentioned by Mr. Tait. An elderly lady had for more than a year had at intervals symptoms of the passage of gall-stones, severe pain requiring morphia, and jaundice; perfect recovery in the intervals. For some weeks before I saw her the intervals had been so shortened that the jaundice of one attack had not time to disappear before the next occurred. Her appetite and strength were failing, so that her condition was becoming precarious. She was believed to have had about 100 attacks. I told her that she might have a hundred or two more stones to pass, and that before the bladder was emptied she might perish from exhaustion; that I considered she was in greater danger from this than she would be from an anæsthetic and the operation. The latter risks I therefore advised her to accept. I have never seen her since, but heard that she had decided to do so, and had placed herself under Mr. Tait for the operation, the result of which he has given in Tre LANCerT of the 13 th inst.

2. A child six years of age was attacked with abdominal symptoms of a mild character, fairly supposed by the family attendant to be due to gastro-intestinal disorder. After three days he one morning became suddenly much worse. As I happened to be away all day on a country journey I did not see him till late at night. He was then in a condition which must pretty evidently be fatal, and which indicated the existence of peritonitis. I advised that the only chance left for him was to have his abdomen opened. This was done by Dr. Malins, and a good many ounces of most abominably fetid pus escaped. He was more comfortable after the operation, but died in about twenty-four hours, and I do not know that his death was either delayed or hastened by the operation. But I assume that a person is more likely to recover without than with a quantity of fetid pus in his abdominal cavity.

3. A boy of twelve was much reduced by peritonitis of three months' standing, and consequent hectic. On the right side of the abdomen, about the ileo-cæecal region, was evidently a collection of what we presumed to be pus. There was on the corresponding left side (where the inflammation had began) tenderness, but no evident collection. 1 advised the friends that it would probably be necessary to open the abdomen. But as they were anxious to avoid this if possible, we agreed to have a further trial of medicine, and gave him some syrup of the iodide of iron and some conium. He improved as to general condition, but after a second relapse, the local conditions remaining unaltered, 1 pressed them to consent to an operation, which they did, and Mr. Tait opened three loculi containing pus, one on the right side, one on the left, and one deeply seated towards the back. There was an immediate return to normal temperature, but there have been two recrudescences of fever, and the case, which it was all along feared might be of a tubercular character, is still in abeyance.

4. A female of about thirty, married, was sail to be suffering from peritonitis. This was undoubtedly so, and her aspect, pulse, temperature, and romiting showed that she was in a very serious condition. She referred her subjective symptoms to the upper part of the abdomen; they had existed severely for several days. But on further inquiry there was a previous history of pain for several days of a slighter character, and in the left ovarian region. Vaginal examination showed a good deal of fulness and extreme tenderness to the left of the uterus. I came to the conclusion that the original seat of disease was the left uterine appendages, and that there was very probably pyo-salpingitis. I advised that if the symptoms did not abate, and still more if they increased, the abdomen should be opened and this region explored. This was done about a fortnight after by Dr. Savage; the appendages were with difficulty removed; the ovary was enlarged and inflamed, and pus was found in the Fallopian tube. The patient did well.

These cases admit of, and indeed suggest, plenty of discussion, comment, and criticism. But into this I do not propose now to enter, my present object being only, as stated at the outset, to show that there are cases hitherto supposed to be purely medical, and as such met with in a purely medical practice, which do admit of, and in my opinion require, surgical interference. These cases were, it will be noticed, treated by gynæcological surgeons; but at least two of them any good general surgeon-one, for example, who would not hesitate to operate for strangulated herniaought to be quite prepared to undertake. 